\title{
Penatalaksanaan Perawatan Saluran Akar Pada Gigi 11 dan Restorasi Porcelain Fused to Metal Crown dengan Custom-made Metal Post and Core
}

Karina Nabilla ${ }^{1}$, Reni Nofika ${ }^{1}$

Korespondensi : Reni Nofika; reninofika@gmail.com; Telp: 081363475034

\begin{abstract}
Dental caies almost infected the pulp. The ernomous of cavity need core as the retention. This paper aimed to describe the management of dental caries to final restoration. A woman aged 22 yearscome to Dental Hospital with chief complain a discoloration on her restorated front teeth. Objective examination showed still vital but spontaneous dull pain recorded from patient. Root canal treatment then suggested with custom made post and core porcelain fused to metal crown as a final restoration.
\end{abstract}

Keywords: root canal treatment; custom made post core; porcelain fused to metal crown

Affiliasi penulis : ${ }^{1}$ Fakultas Kedokteran Gigi, Universitas Andalas

PENDAHULUAN

Karies gigi atau "tooth decay" disebut juga sebagai penyakit mikrobiologi yang mempengaruhi secara lokal di rongga mulut dan secara sistemik pada kasus ekstrim. Patobiologi karies gigi dihasilkan dari terlarutnya struktur mineral gigi, dari tiga komponen dasar yang ditemukan saat manifestasi klinis karies, diantaranya struktur gigi, bakteri asidogenik, karbohidrat yang terfermentasi untuk dimetabolisme oleh bakteri. Pulpa gigi merupakan jaringan ikat yang mengandung saraf, pembuluh darah, substansi dasar, cairan intertisial, odontoblast, fibroblast, dan komponen selular lainnya. Perawatan saluran akar dilakukan pada kondisi gigi dengan patologis pulpa atau periapikal. Selain itu, terdapat kondisi yang menjadi pilihan untuk dilakukan perawatan saluran akar, diantaranya pada gigi yang telah dilakukan pemasangan mahkota jaket dan butuh dilakukan pasak, gigi dengan overdenture, dan gigi dengan vitalitas pulpa yang meragukan. ${ }^{1,2}$

Pembuatan restorasi gigi setelah perawatan endodonti merupakan kelanjutan dari rangkaian perawatan endodonti yang telah dilakukan, untuk mengembalikan fungsi fisiologis dan fungsi estetik gigi dan merupakan tahap akhir dalam keberhasilan perawatan endodonti. Tujuan restorasi pada gigi pasca perawatan endodonti yaitu mempertahankan kerapatan setelah pengisian saluran akar atau mencegah microleakage, mempertahankan jaringan gigi yang tersisa, dan mempertahankan fungsi dan estetik. Faktor yang harus diperhatikan untuk keberhasilan pembuatan restorasi akhir setelah perawatan endodonti antara lain struktur dentin yang tersisa, hilangnya struktur gigi, perubahan warna gigi, perbandingan antara mahkota dan akar yang masih tertinggal, dan keadaan sosial ekonomi pasien. ${ }^{2,3}$ 
Terdapat beberapa jenis restorasi yang dapat digunakan setelah perawatan saluran akar. Jika sisa jaringan keras gigi masih banyak maka gigi dapat direstorasi menggunakan resin komposit secara direk untuk mendapatkan hasil yang memuaskan. Apabila terdapat kavitas tambahan atau adanya perluasan kavitas akibat prosedur restorasi maka perlu dipertimbangkan penggunaan pasak untuk memperkuat restorasi. ${ }^{4}$ Pasak atau post adalah bangunan yang terbuat dari logam atau bahan restoratif kaku yang dimasukkan dalam saluran akar gigi. Pasak berfungsi untuk menambah retensi restorasi dan meneruskan tekanan yang diterima gigi merata ke sepanjang akar. Pasak dapat dibedakan menjadi beberapa macam yaitu berdasarkan cara pembuatannya pasak dapat dibedakan menjadi dua yaitu pasak prefabricated dan custom-fabricated/custom-made, sedangkan berdasarkan bahan pembuatannya yaitu pasak logam dan non logam. Penggunaan inti atau core dibutuhkan jika jaringan gigi yang tersisa sangat kurang, sehingga tidak dapat memberikan retensi pada restorasi korona. ${ }^{5}$

Custom-made metal post and core telah digunakan selama beberapa decade terakhir sebagai fondasi dari restorasi. Custom-made cast metal post adalah pilihan pasak untuk gigi berakar tunggal, terutama ketika sisa struktur gigi untuk mendukung mahkota minimal. Kelebihan penggunaan jenis pasak ini antara lain adalah dapat beradaptasi pada saluran akar berukuran besar dan ireguler, kekuatan yang sangat kuat, retensi inti yang lebih baik karena inti dan pasak berada pada satu bagian yang inherent, harga yang lebih efektif pada gigi berakar multipel, pilihan yang lebih baik untuk gigi berukuran kecil, dapat mengoreksi inklinasi gigi. ${ }^{5}$ Restorasi akhir setelah pembuatan pasak inti logam dapat berupa mahkota jaket porselen fusi metal atau porcelain fused to metal crown. Keunggulan dari mahkota PFM ini antara lain memiliki kekuatan yang lebih tinggi serta estetik yang memuaskan dikarenakan kombinasi bahan porselen dan metal, resistensi yang lebih adekuat, preparasi yang dibutuhkan lebih sedikit dibandingkan dengan mahkota porselen penuh. ${ }^{6}$

\section{KASUS}

Pasien perempuan 22 tahun datang ke Klinik Fakultas Kedokteran Gigi Universitas Andalas dengan keluhan gigi depan berubah warna atau menghitam dan tambalannya retak. Dari anamnesis diketahui keluhan dirasakan semenjak lebih kurang 6 bulan yang lalu. Gigi tersebut awalnya berlubang, dan ditambal 4 tahun yang lalu tetapi tambalan dibuat menyatu dengan gigi sebelahnya dan retak sejak 4 bulan yang lalu. Gigi pasien pernah berdenyut spontan, terkadang ngilu saat makan makanan manis dan minum air dingin. Riwayat kesehatan umum pasien baik, tidak pernah dirawat dirumah sakit. Alergi obat dan makanan tidak ada. Riwayat kesehatan keluarga menunjukkan Ayah memiliki penyakit hipertensi, Ibu, saudara sekandung tidak dicurigai adanya penyakit sistemik. Pasien menyikat gigi 2 kali sehari (pagi dan sore saat mandi). Pasien pernah ke dokter gigi sebelumnya 4 tahun yang lalu untuk menambal gigi.

Pada pemeriksaan klinis ditemukan adanya perubahan warna pada gigi serta fraktur vertikal pada tambalan. Tes termal (+), perkusi (+), palpasi (-), tekan (-), serta mobility tidak menunjukkan kelainan. 

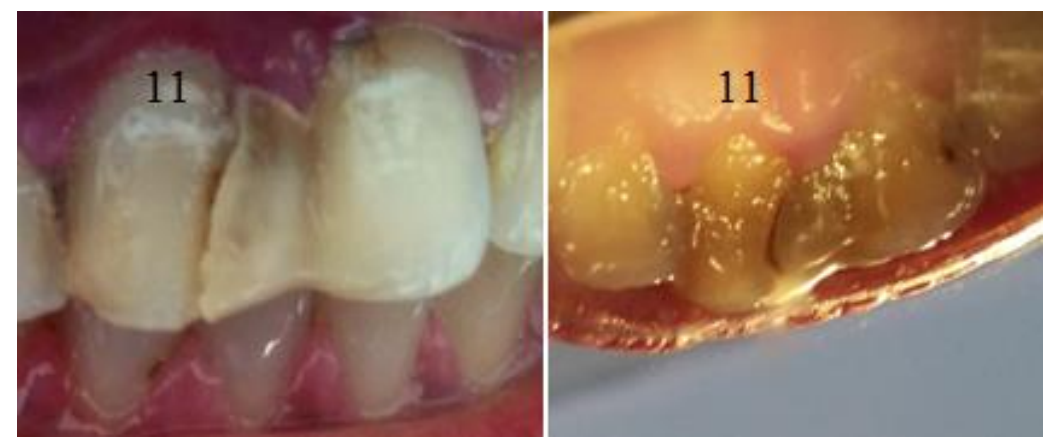

Gambar 1. Foto klinis gigi 11

Pada pemeriksaan radiografi dilakukan rontgen periapikal gigi 11 yang menunjukkan gambaran radiopak pada mesial dan distal gigi yang mendekati kamar pulpa, saluran akar lurus, terdapat pelebaran ligamen periodontal pada sepanjang akar.

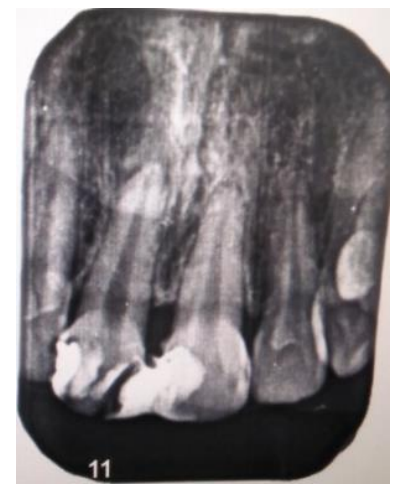

Gambar 2. Hasil foto periapikal gigi 11

Berdasarkan anamnesa dan pemeriksaan objektif dapat disimpulkan bahwa diagnosis pada kasus ini adalah pulpitis irreversibel simtomatik disertai periodontitis apikalis simtomatik dengan rencana perawatan saluran akar. Prognosis kasus ini baik karena masih terdapat struktur jaringan gigi yang cukup untuk dapat dilakukan restorasi, pasien kooperatif, saluran akar dapat diakses.

\section{TATA LAKSANA KASUS}

\section{Kunjungan 1}

Kunjungan awal pada 26 Juli 2018, pasien datang ke RSGM FKG Unand untuk dilakukan pemeriksaan lengkap, berupa pemeriksaan subjektif, objektif, foto intraoral, dan pemeriksaan penunjang rontgen foto periapikal, serta dilakukan pengukuran panjang kerja estimasi. Dari hasil pemeriksaan menunjukkan adanya perubahan warna pada gigi 11 dan tambalan yang retak. Pemeriksaan radiografi terlihat adanya gambaran karies yang mencapai pulpa serta pelebaran ligament periodontal. Rencana perawatan yang dilakukan adalah perawatan saluran akar.

\section{Kunjungan 2}

Tanggal 8 November 2018, pasien datang untuk melakukan perawatan saluran akar. Persiapan sebelum perawatan dilakukan berupa pengisian informed consent dan pemeriksaan ulang keadaan gigi 11 . Prosedur pertama yang dilakukan adalah infiltrasi gigi 11 bagian bukal dengan pehacain 0,5-1 ml menggunakan spuit $1 \mathrm{cc}$, lalu pembuangan tambalan lama serta jaringan karies dengan metal round bur 
serta pembuangan enamel yang tidak didukung dentin dengan diamond cylindrical bur. Build-up dilakukan pada bagian labial gigi menggunakan resin komposit untuk mempertahankan estetis. Buka atap pulpa dengan diamond round bur dan buang atap kamar pulpa dengan mengggunakan safe-end bur (diamendo) dan ekskavator lalu irigasi dengan Aquades. Cari orifice dengan sonde lurus, dan ekstirpasi pulpa dengan jarum ekstirpasi, lalu irigasi dengan $\mathrm{NaOCl}$ 2,5\% dan Aquades. Kavitas ditutup dengan kapas berisi uap ChKm dan caviton pada bagian palatal.

\section{Kunjungan 3}

Tanggal 15 November 2018, perawatan dilanjukan dengan preparasi saluran akar menggunakan teknik step back serta tentukan IAF yaitu nomor file yang pertama kali bisa masuk sepanjang kerja di saluran akar (K-file \#80 panjang kerja $20 \mathrm{~mm}$ ). Dikarenakan ukuran IAF pasien besar, maka tidak dilakukan pembesaran apical sehingga pada kasus ini IAF=MAF. Ukuran MAF akan sama dengan MAC (Master Apical Cone = cone gutta percha utama). Irigasi dengan $\mathrm{NaOCl} 2,5 \%$ dan Aquades secara bergantian dan lanjutkan dengan preparasi badan saluran akar. Preparasi badan saluran akar dimulai dengan file satu ukuran lebih besar dari MAF dan dikurangi $1 \mathrm{~mm}$ dari panjang kerja (80/20, 90/19, 100/18, 110/17). Irigasi dengan $\mathrm{NaOCl}$ 2,5\% dan Aquades setiap pergantian file. Haluskan dinding saluran akar dengan MAF gerakan circumferential-filing. Irigasi, dan keringkan dengan paper point. Aplikasi $\mathrm{Ca}(\mathrm{OH}) 2$ lalu tutup dengan kapas steril dan kaviton.

\section{Kunjungan 4}

Tanggal 28 November 2018, pasien datang untuk melakukan rotasi obat. Hasil pemeriksaan keluhan $(-)$, tambalan sementara dan build-up komposit (+) perkusi (+). Bahan medikamen dikeluarkan dari saluran akar, lalu saluran akar direndam dengan Chlorhexidine $2 \%$ selama 1 menit, irigasi dengan Aquades lalu keringkan dengan paper point. Aplikasi $\mathrm{Ca}(\mathrm{OH}) 2$ dan tutup dengan tambalan sementara.

\section{Kunjungan 5}

Tanggal 12 Desember 2018, hasil pemeriksaan keluhan (-) perkusi (-), sehingga dilakukan rontgen foto trial dengan gutta percha no 80 . Hasil foto rontgen menunjukkan panjang kerja estimasi sesuai panjang saluran akar.

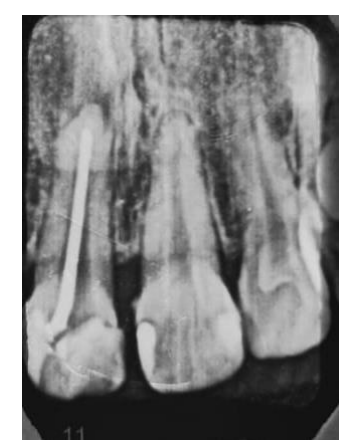

Gambar 3. Hasil foto trial 


\section{Kunjungan 6}

Pada tanggal 14 Desember 2018, dilakukan obturasi pada gigi 11 dengan bahan gutta percha dengan sealer. Teknik obturasi yang digunakan adalah Lateral Condensation Technique ditentukan melalui rontgen foto trial. Bongkar tambalan sementara, keluarkan cotton pellet,irigasi saluran akar dengan Aquades, genangi saluran akar menggunakan larutan Chlorhexidine $2 \%$ selama 5 menit, lalu keringkan dengan paper point.Siapkan gutta percha, rendam ke dalam $\mathrm{NaOCl}$ selama 1 menit lalu basahi dengan alkohol.

Aduk semen sealer (endometason yang dicampur dengan eugenol di atas glass lab) kemudian aplikasikan kedalam saluran akar dengan lentulo dan olesi ke gutta percha. Masukkan satu gutta perca sebesar MAC (MAC = \#80) ke dalam saluran akar. Gunakan spreader untuk memadatkan gutta percha ke samping. Lakukan pengisian dengan gutta percha aksesoris sampai saluran akar terisi penuh. Setelah saluran akar terisi penuh, potong gutta percha dengan instrumen yang dipanaskan hingga batas orifis dan tekan menggunakan plugger panas. Berikan lining pada dasar kamar pulpa menggunakan semen fosfat. Tutup dengan tambalan sementara, dan lakukan rontgen foto. Dari hasil rontgen terlihat obturasi padat dan hermetis.

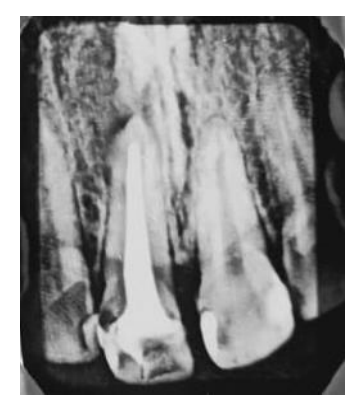

Gambar 4. Rontgen foto obturasi

\section{Kunjungan 7}

Pada tanggal 28 Desember 2018, pasien datang untuk melakukan kontrol pasca obturasi. Hasil pemeriksaan berupa keluhan (-), tes perkusi (-), palpasi (-).

\section{Kunjungan 8}

Pada tanggal 2 Mei 2019, pasien datang untuk melanjutkan perawatan restorasi akhir berupa mahkota dan pasak inti. Pada kunjungan ini dilakukan pengeluaran gutta percha. Tambalan sementara dan semen fosfat dibongkar menggunakan scaller, lakukan akses awal dengan gates-glidden drill (\#1-\#4) sesuai panjang kerja post $(16 \mathrm{~mm})$. Keluarkan sisa gutta percha dengan peeso reamer nomor yang sama sesuai panjang kerja. Buang sisa sealer yang menempel pada dinding saluran akar dengan $k$-file dengan gerakan circumferential filing bertekanan ringan dan irigasi dengan Aquades. Saluran akar dikeringkan, lalu tutup dengan kapas steril dan kaviton. Selanjutnya, dilakukan rontgen foto untuk melihat pengambilan gutta percha sudah tepat/belum. Pada tahap ini, pengurangan gutta percha dilakukan $3 x$ hingga gutta percha yang tersisa disaluran akar tepat $4 \mathrm{~mm}$. 


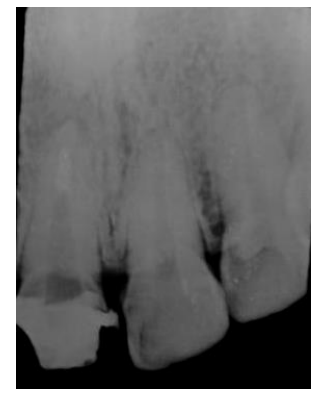

Gambar 5. Rontgen pengambilan gutta percha

\section{Kunjungan 9}

Tanggal 8 Mei 2019 dilakukan pencetakan saluran akar dengan green stick compound. Saluran akar diirigasi dengan Aquades steril dan dikeringkan dengan paper point, lalu green stick compound dipanaskan dan diolesi ke paper clip yang telah dipotong lalu dimasukkan kedalam saluran akar.Setelah lilin mengeras, keluarkan dan periksa apakah cetakan saluran akar tidak terdapat porus/retak.

\section{Kunjungan 10}

Tanggal 15 Mei 2019 dilakukan preparasi pada sisa mahkota. Mahkota yang akan dibuatkan adalah porcelain fused to metal crown. Jaringan mahkota yang tersisa cukup untuk mendapatkan efek ferrule, sehingga desain preparasi mahkota pasak menyesuaikan dengan kebutuhan preparasi mahkota PFM. Preparasi dilakukan dengan pengurangan $1 \mathrm{~mm}$ pada oklusal, $2 \mathrm{~mm}$ bagian labial, $1 \mathrm{~mm}$ palatal, dan akhiran dibentuk equigingiva pada labial dengan desain shoulder dan supragingiva pada palatal dengan desain chamfer. Sudut-sudut preparasi dihaluskan dengan bur pita kuning. Setelah preparasi selesai, dibuatkan mahkota sementara dengan bahan self cure acrylic dan disementasi menggunakan freeugenol.

\section{Kunjungan 11}

Tanggal 4 Juli 2019, pada kunjungan ini dilakukan pembuatan inlay post\&core dengan inlay wax. Paper clip dipotong secukupnya dan diberi guratan menggunakan bur, inlay wax dipanaskan lalu diteteskan ke kawat hingga ketebalan yang cukup, lalu masukkan kedalam saluran akar. Cetakan inlay wax untuk pasak harus dibuat sesuai dengan cetakan awal yang dibuat dengan green stick compound. Setelah didapatkan inlay post yang sesuai, dilanjutkan dengan pembuatan inlay core dengan inlay wax diteteskan hingga membentuk inti yang sesuai. Permukaan lilin dipoles dengan alkohol, lalu dikirimkan ke lab untuk casting logam.

\section{Kunjungan 12}

Tanggal 16 Agustus 2019, dilakukan try-in pasak dan inti logam. Pemeriksaan adapatasi tepi, retensi, stabilisasi dilakukan. Setelah itu dilakukan insersi dengan bahan sementasi GIC luting. Saluran akar direndam dengan Chlorhexidine 2\% selama 2 menit, lalu dikeringkan. Aduk GIC luting hingga konsistensi pasta, aplikasikan kedalam saluran akar dengan lentulo, dan oleskan pada bagian pasak logamnya. Insersikan pasak logam dengan gerakan seperti memompa agar semen merata dengan baik, lalu posisikan pasak hingga final rest position, tekan hingga semen mengeras. Buang kelebihan semen dengan sonde. 
Fakultas Kedokteran Gigi Universitas Andalas

Jalan Perintis Kemerdekaan No. 77 Padang, Sumatera Barat

Web: adj.fkg.unand.ac.id Email: adj@dent.unand.ac.id

Setelah pasak inti terpasang, dilakukan pembuatan mahkota sementara yang baru menggunakan self cure acrylic.

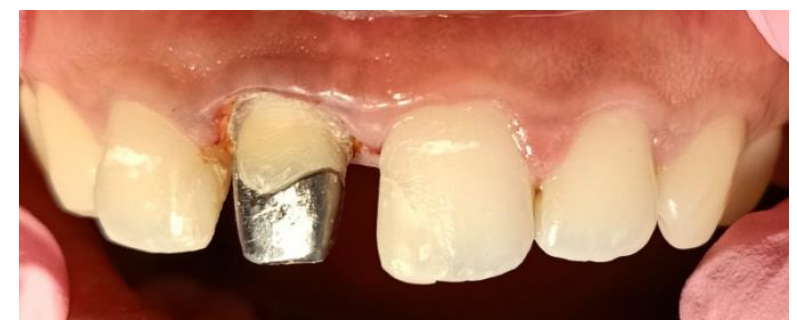

(a)

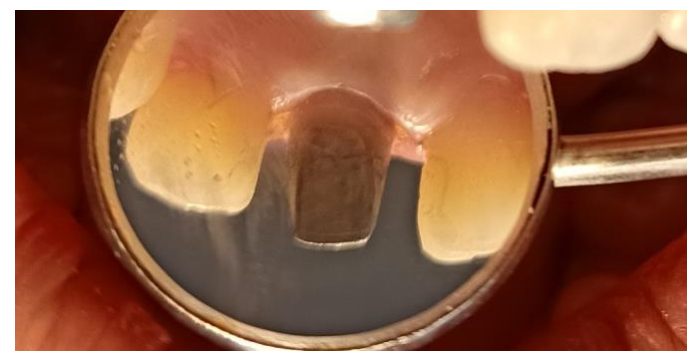

(c)

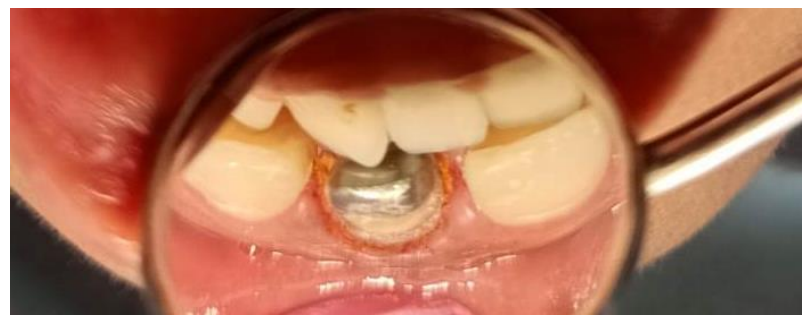

(b)

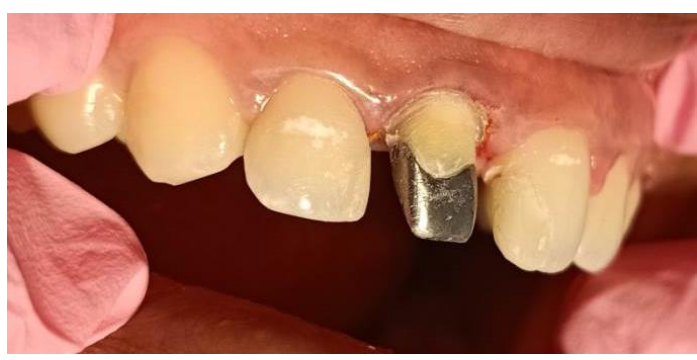

(d)

Gambar 6. Foto klinis pasca insersi pasak inti logam (a)tampak labial, (b)oklusi,(c)tampak palatal,(d)lateral Kunjugan 13

Tanggal 21 Agustus 2019 dilakukan finishing \& polishing core serta pencetakan double impression. Bagian inti logam yang tajam dihaluskan menggunakan white stone bur, setelah itu dilakukan pencetakan dengan bahan putty heavy body dan light body. Pencetakan gigi antagonis dilakukan dengan bahan alginate, dan catatan gigitan dibuat. Hasil cetakan kemudian dikirim ke lab untuk prosesing mahkota.

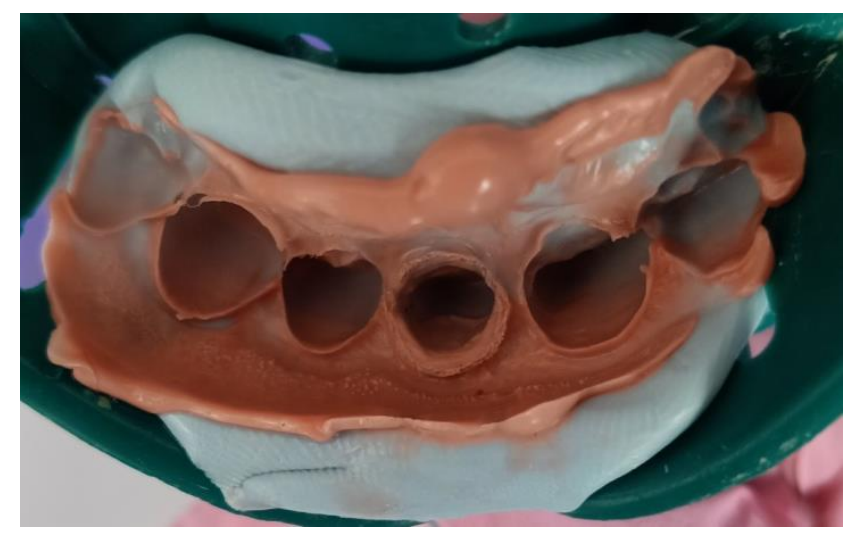

Gambar 7. Hasil pencetakan teknik double impression 
ANDALAS DENTAL JOURNAL

Fakultas Kedokteran Gigi Universitas Andalas

Jalan Perintis Kemerdekaan No. 77 Padang, Sumatera Barat

Web: adj.fkg.unand.ac.id Email: adj@dent.unand.ac.id

\section{Kunjungan 14}

Tanggal 7 Oktober 2019 dilakukan try in mahkota PFM. Pada saat try-in, kerapatan mahkota, kontrak proksimal dan oklusal diperiksa dengan sonde, lalu keadaan gigi saat try-in (tes perkusi (-) palpasi (-)). Setelah itu, dilakukan insersi dengan bahan sementasi GIC luting.

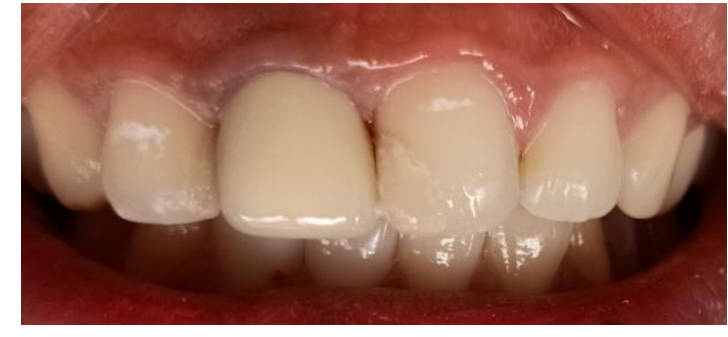

(a)

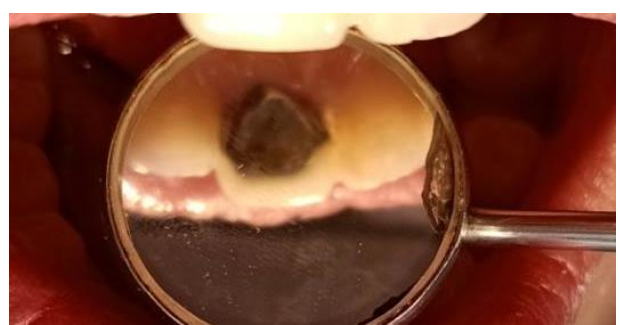

(b)

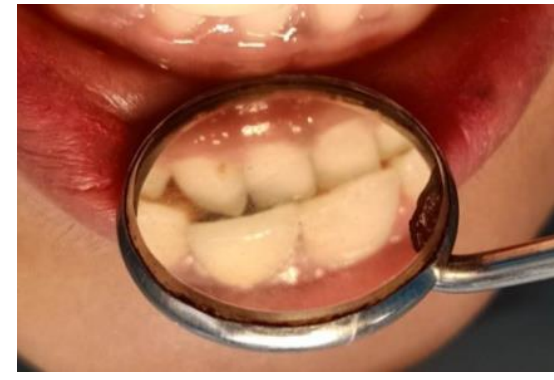

(c)

Gambar 8. Foto klinis pasca insersi mahkota PFM (a) tampak labial, (b) tampak palatal, (c) oklusi

\section{Kunjungan 15}

Tanggal 15 Oktober 2019 pasien datang untuk melakukan kontrol 1 minggu mahkota PFM. Diketahui keluhan (-), tes perkusi (-), tes palpasi (-), TO (-), keadaan jaringan sekitar gigi baik, plak dan debris (-).

\section{Kunjungan 16}

Tanggal 5 Desember 2019, pasien datang untuk kontrol sebulan pasca insersi mahkota. Pasien tidak memiliki keluhan tetapi dari pemeriksaan terlihat black line di gusi bagian servikal terlihat jelas, keadaan gingival normal tidak terdapat pembengkakan atau kemerahan. Hasil pemeriksaan gigi tes perkusi (-) palpasi (-) traumatik oklusi (-) dan terdapat plak dan debris disekitar mahkota gigi.

\section{DISKUSI}

Pasak atau post adalah bangunan yang terbuat dari logam atau bahan restoratif kaku yang dimasukkan dalam saluran akar gigi. Pasak berfungsi untuk menambah retensi restorasi dan meneruskan tekanan yang diterima gigi merata ke sepanjang akar. Pasak dapat dibedakan menjadi beberapa macam yaitu berdasarkan cara pembuatannya pasak dapat dibedakan menjadi dua yaitu pasak prefabricated dan custom-fabricated/custom-made, sedangkan berdasarkan bahan pembuatannya yaitu pasak logam dan 
non logam. Penggunaan inti atau core dibutuhkan jika jaringan gigi yang tersisa sangat kurang, sehingga tidak dapat memberikan retensi pada restorasi korona. 5,6

Prinsip desain preparasi untuk pasak yang ideal meliputi beberapa aspek seperti apical seal yang adekuat, pembesaran saluran akar yang minimal (tidak terdapat undercut), panjang pasak yang adekuat, positive horizontal stop, adanya dinding vertikal untuk mencegah rotasi, dan ekstensi margin restorasi akhir ke struktur gigi yang tersisa (Gambar 9). Untuk menyediakan ruang pasak pada saluran akar, pembuangan jaringan gigi harus seminimal mungkin untuk menghindari terjadinya fraktur akar dan perforasi. Ketebalan dentin yang tersisa merupakan variable utama dari resistensi fraktur pada akar. Oleh karena itu, saluran akar harus diperbesar secukupnya hingga pasak secara akurat beradaptasi dan retentif. Pada ruang saluran pasak yang taper, pembesaran saluran akar dilakukan hingga 1-2 ukuran file yang lebih besar dari yang digunakan saat perawatan saluran akar, hal ini disebabkan pasak bagian korona memiliki lebar yang lebih besar. ${ }^{6}$

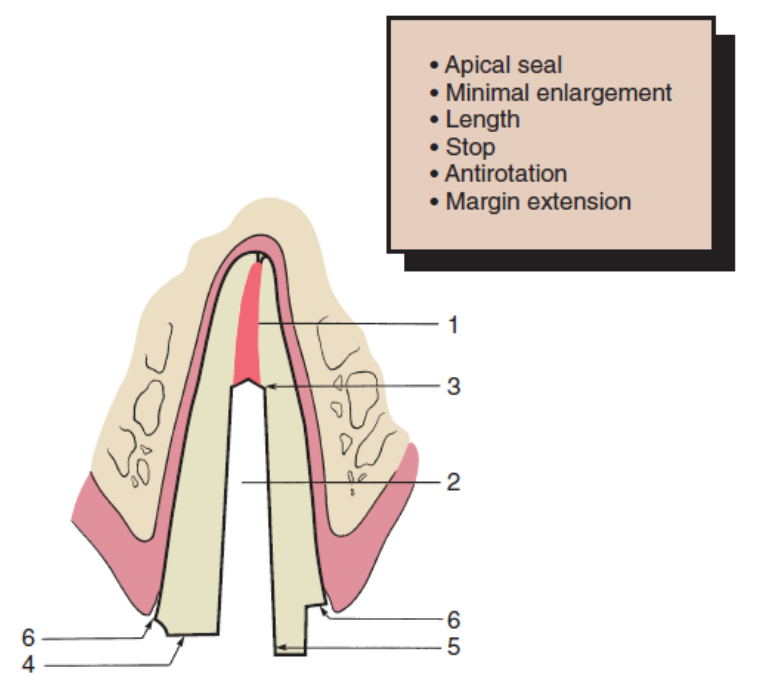

Gambar 9. Prinsip ideal preparasi pasak. (1) apical seal yang adekuat, (2) pembesaran saluran akar yang minimal (tidak terdapat undercut), (3) panjang pasak yang adekuat, (4) positive horizontal stop, (5) adanya dinding vertikal untuk mencegah rotasi, (6) ekstensi margin restorasi akhir ke struktur gigi yang tersisa

Preparasi mahkota pasca perawatan endodonti mengikuti jenis restorasi akhir yang akan digunakan, Pada kasus restorasi pasak inti logam, pengurangan jaringan gigi lebih banyak dilakukan untuk mengakomodasi ruangan untuk mahkota penuh dan diperlukannya eliminasi undercut pada saluran akar. Ekstensi dinding aksial dari mahkota bagian apikal terhadap struktur gigi tersisa membentuk suatu restorasi yang disebut ferrule, yang didefinisikan sebagai lingkaran logam atau cincin yang berfungsi mengadaptasikan akar atau mahkota gigi, berbeda dengan restorasi crown yang hanya mengelilingi bahan dari inti (Gambar 10). Ketinggian dinding aksial dari struktur gigi sebesar 1.5-2 mm dan ketebalan minimal 1 $\mathrm{mm}$ secara signifikan dapat mengurangi insiden terjadinya fraktur, kondisi ini disebut dengan ferrule effect (Gambar 11). Semakin panjang tinggi ferrule, semakin baik prognosisnya. Ferrule berfungsi meningkatkan resisten terhadap fraktur dengan menyerbarkan gaya atau tekanan yang diterima area servikal menuju kearah eksternal (Gambar 12), mencegah timbulnya gaya/tekanan lateral dari pasak dan ungkitan mahkota saat pengunyahan. 6,7 
Fakultas Kedokteran Gigi Universitas Andalas

Jalan Perintis Kemerdekaan No. 77 Padang, Sumatera Barat

Web: adj.fkg.unand.ac.id Email: adj@dent.unand.ac.id

A
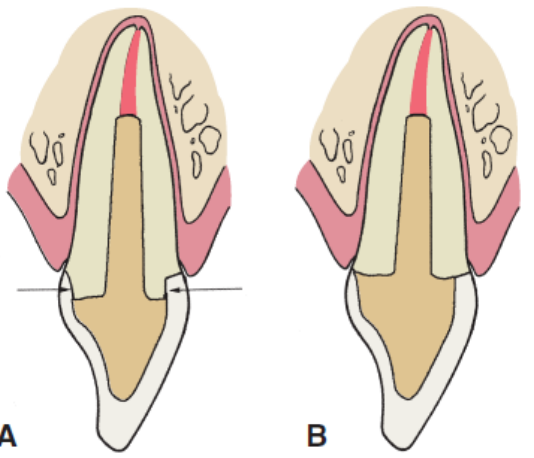

Gambar 10. (a) preparasi dengan ferrule (b) preparasi tanpa ferrule

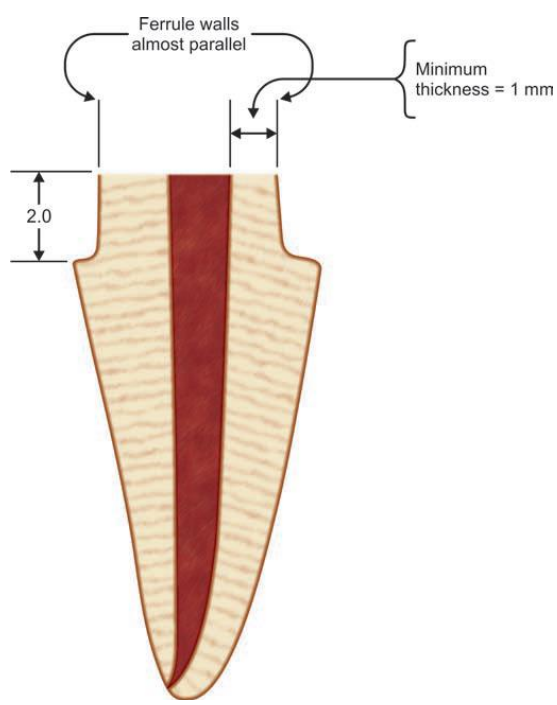

Gambar 11. Diagram ferrule effect

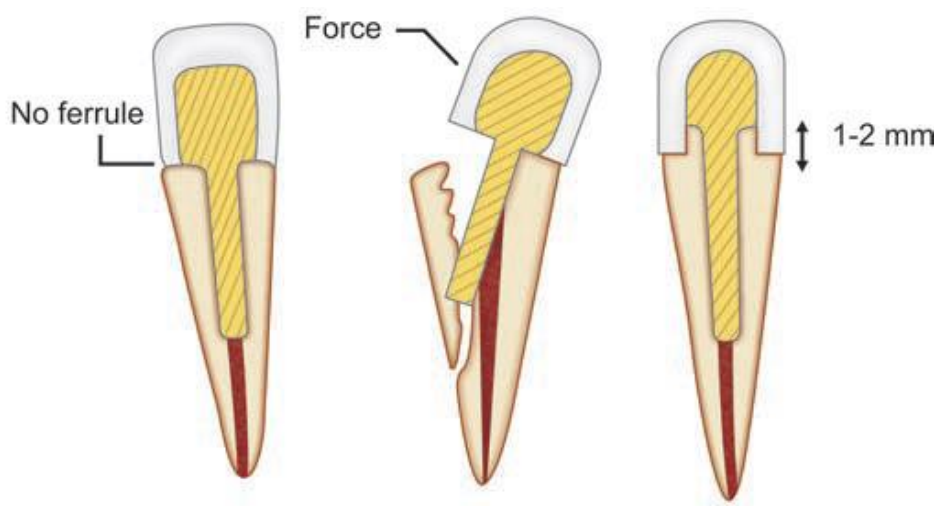

Gambar 12. Fungsi ferrule effect untuk mencegah terjadinya fraktur

Retensi dari pasak dipengaruhi oleh geometri preparasi, panjang pasak, diameter pasak, tekstur permukaan pasak, dan luting agent. Bentuk saluran akar yang membulat dapat dipreparasi menggunakan twist drill atau reamer untuk menbentuk dinding kavitas yang paralel. Saluran akar dengan bentuk penampangnya elips atau melonjong harus dipreparasi mengerucut ke apikal yang terbatas 6-8 derajat, hal ini untuk memastikan adanya retensi yang adekuat dan mengeliminasi undercut yang tidak diinginkan. 
Walaupun retensi dapat ditingkatkan dengan penggunaan pasak berulir yang tertanam di dentin, prosedur ini tidak direkomendasikan karena dapat membentuk residual stress pada dentin yang akan menyebabkan fraktur akar. ${ }^{5}$

Studi menunjukkan semakin besar panjang pasak maka retensinya pun semakin besar. Tetapi, pernyataan tersebut tidak selalu benar. Pasak yang terlalu pendek akan menimbulkan kegagalan, sementara pasak yang terlalu panjang dapat merusak seal saluran akar atau beresiko perforasi akar jika sepertiga apikal melengkung atau taper. Idealnya, panjang pasak harus cukup besar tanpa merusak apical seal atau merusak struktur akar. Sebagian besar endondontis menyarankan untuk mempertahankan $5 \mathrm{~mm}$ apical seal. Namun, jika pasak lebih pendek daripada tinggi mahkota klinis, prognosisnya akan meragukan, sebab tekanan terdistribusi ke permukaan yang lebih kecil akan menimbulkan fraktur pada radikular. ${ }^{5}$

Menambah besar diameter pasak untuk meningkatkan retensi tidak dianjurkan karena hanya akan mendapatkan retensi minimal dan pengambilan jaringan sisa akar yang tidak diperlukan. Studi empirik menunjukkan prognosis yang baik dari pasak didapatkan apabila diameter pasak tidak melebihi sepertiga dari diameter akar secara cross-sectional. ${ }^{5}$

Pemilihan jenis semen dilihat dapat mempengaruhi retensi pasak. Bahan semen resin adhesive memiliki potensi untuk meningkatkan performa restorasi pasak dan inti. Semen resin dapat dipengaruhi oleh sealer berbahan dasar eugenol yang terdapat pada saluran akar, sehingga harus dihilangkan dengan irigasi menggunakan ethanol atau etsa dengan 37\% asam fosforik untuk hasil yang lebih efektif. Semen fostat dan GIC memiliki sifat retensi yang serupa dengan semen resin, dimana polikarboksilat dan semen resin komposit memiliki sifat yang lebih lemah. ${ }^{5}$

\section{SIMPULAN}

Laporan kasus ini membahas mengenai perawatan saluran akar dengan diagnosis pulpitis ireversibel simtomatik disertai periodontitis apikalis simtomatik pada gigi 11. Kasus ini memerlukan restorasi yang estetis disebabkan posisi gigi terletak pada anterior rahang atas dan akan mempengaruhi pasien untuk percaya diri saat tersenyum dan berbicara.

Pada kasus ini digunakan custom metal post and core dengan mahkota porcelain fused to metal. Pemilihan disebabkan oleh saluran akar pasien yang besar, dan sisa struktur mahkota gigi yang tidak cukup untuk dilakukan restorasi jenis direk. Restorasi mahkota porcelain fused to metal berdasarkan penggunaan custom metal post and core yang juga berbahan metal, sehingga memiliki kekuatan yang lebih tinggi serta estetik yang memuaskan dikarenakan kombinasi bahan porselen dan metal, resistensi yang lebih adekuat, preparasi yang dibutuhkan lebih sedikit dibandingkan dengan mahkota porselen penuh.

\section{KEPUSTAKAAN}

1. Perawatan Saluran Akar pada Gigi Incisivus Sentral dan Lateral Maksila dengan Perbedaan Status Pulpa: Laporan Kasus Endodontic Treatment of Maxillary Central and Lateral Incisor with Different Pulp Status: A Case Report Yusrini Pasril Insisiva Dental Journal, Mei, 2017: vol. 6(1). 
2. Perawatan Saluran Akar Satu Kunjungan disertai Restorasi Resin Komposit dengan Pasak Parallel Self-Threading Gigi Molar Kedua Kanan Mandibula Pulpitis Ireversibel Gunawan Raharjo* dan Pribadi Santosa**KKGK. Juni, 2015; 1(1): 63-70.

3. Ardana, Emy dan Aries. Pasak estetik dari bahan fiber reinforced composite. Dentofasial, 2013: vol.12(1). ISSN:1412-8926.

4. Subroto, et al., Pasak Customized Fiber Reinforced Composite Indirect pada Gigi Incisivus Lateralis Kiri Atas dengan Dinding Saluran Akar yang Tipis. Maj Ked Gi Ind. 2015; 1(1): 109 - 114. ISSN 2460-0164.

5. Besse T. Awaru dan Juni J. Nugroho. Restorasi pada gigi anterior setelah perawatan endodontic. Dentofasial, 2012: Vol.11(3). ISSN:1412-8926.

6. Rosenstiel, Land, Fujimoto. Contemporary Fixed Prosthodontics. Fourth Edition. Missouri: Elsevier. 2006, pp. 337-346.

7. Nisha Garg, Amit Garg. Texbook of Endodontics. Third Edition. New Delhi : Jaypee. 2014, pp. 432-433. 